\title{
Article/Artigo
}

\section{Detection and molecular analysis of Toxoplasma gondii and Neospora caninum from dogs with neurological disorders}

\author{
Detecção e análise molecular de Toxoplasma gondii e Neospora caninum em cães com distúrbios \\ neurológicos
}

\author{
Helio Langoni ${ }^{1}$, Guilherme Matteucci ${ }^{1}$, Bruno Medici $^{1}$, Lucilene Granuzio Camossi $^{1}$, Virgínia Bodelão Richini-Pereira ${ }^{1}$ \\ and Rodrigo Costa da Silva ${ }^{1}$
}

\begin{abstract}
Introduction: Toxoplasma gondii and Neospora caninum are related Apicomplexa parasites responsible for systemic diseases in many species of animals, including dogs. Methods: This study aimed to determine the occurrence of T. gondii and N. caninum infections in 50 dogs with neurological signs that were admitted to the Veterinary Hospital of Universidade Estadual Paulista, City of Botucatu, Brazil. All animals were screened for antibodies using an immunofluorescent antibody test for both parasites. Tissues of positive animals were bioassayed in mice (T. gondii) and gerbils (N. caninum), and DNA was analyzed using the polymerase chain reaction (PCR). Positive samples for T. gondii by PCR were typed using restriction fragment length polymorphism-PCR for 11 markers: SAG1, SAG2 (5'-3'-SAG2 and alt.SAG2), SAG3, Btub, GRA6, L358, c22-8, c29-6, PK1 and Apico, and CS3 marker for virulence analysis. Results: Specific antibodies were detected in 11/50 (22\%; 95\% confidence interval (CI95\%), 12.8-35.3\%) animals for T. gondii and $7 / 50$ (14\%; CI95\%, 7.02-26.3\%) for N. caninum. In the bioassay and PCR, 7/11 (63.6\%; CI95\%, 34.9-84.8\%) samples were positive for T. gondii and 3/7 (42.9\%; CI95\%I, 15.7-75.5\%) samples were positive for $N$. caninum. Three different genotypes were identified, but only 1 was unique. Conclusions: These data confirm the presence of T. gondii and N. caninum in dogs from Brazil, indicating the importance of this host as a sentinel of T. gondii for human beings, and the genotypic variation of this parasite in Brazil.
\end{abstract}

Keywords: Toxoplasma gondii. Neospora caninum. Genotypes. Dogs. RFLP-PCR. Zoonosis.

\section{RESUMO}

Introdução: Toxoplasma gondii e Neospora caninum são parasitas Apicomplexa responsáveis por doenças sistêmicas em muitas espécies de animais, incluindo cães, o que representa grande importância em animais de estimação. Métodos: Este estudo teve como objetivo determinar a prevalência da infecção de T. gondii e N. caninum em 50 cães com sinais neurológicos internados no Hospital Veterinário da Universidade Estadual Paulista (UNESP) na Cidade de Botucatu, Brasil. Todos os animais foram examinados para detecção de anticorpos por IFAT para ambos os parasitas. Tecidos de animais positivos foram analisados por bioensaio em camundongos (T.gondii) egerbilos (N.caninum) eoDNAfoipesquisadopor PCR.Amostras positivaspara T.gondii por PCR foram analisadas por meio de análise de restrição de fragmentos polimórficos (restriction fragment length polymorphism-polymerase chain reaction-RFLP-PCR), utilizando-se 11 marcadores: SAG1, SAG2 (5'-3'SAG2 e, alt.SAG2), SAG3, Btub, GRA6, L358, c22 -8, C29-6, PK1 e Apico e o marcador CS3 para análise de virulência. Resultados: Os anticorpos específicos foram detectados em $11 / 50$ animais (22\%; IC95\% 12,8-35,3\%) para T. gondii, e 7/50 (14\%; IC95\% 7,0-26,3\%) para N. caninum. No bioensaio e PCR, 7/11 (63,6\%; IC95\% 34,9-84,8\%) das amostras foram positivas para T. gondii, e $3 / 7$ (42,9\%; IC95\% 15,7-75,5\%) para N. caninum. Três diferentes genótipos foram identificados. Apenas um foi único. Conclusões: Estes dados confirmam a presença de T. gondii e N. caninum em cães do Brasil, e demonstra a importância do T. gondii como sentinela para a infecção e a variação genotípica deste parasita no Brasil.

Palavras-chaves: Toxoplasma gondii. Neospora caninum. Genótipos. Cães. RFLP-PCR. Zoonoses.

1. Departamento de Higiene Veterinária e Saúde Publica, Faculdade de Medicina Veterinária e Zootecnia, Universidade Estadual Paulista, Botucatu, SP.

Address to: Dr. Helio Langoni. Dept ${ }^{\circ}$ Higiene Veterinária e Saúde Pública/FMVZ/UNESP. Distrito de Rubião Júnior s/n, Campus de Botucatu, SP, Brasil, 18618-970 Botucatu, SP, Brasil.

Phone: 55 14 3811-6270; Fax: 55 143811-6075.

e-mail: hlangoni@fmvz.unesp.br

Received in 07/07/2011

Accepted in 30/09/2011

\section{INTRODUCTION}

Neospora caninum and Toxoplasma gondii are related coccidian intracellular protozoan parasites that infect many warm-blooded vertebrates causing systemic disease in many species of animals, including production animals and $\operatorname{dog} s^{1,2}$. Clinical canine toxoplasmosis rarely results from a primary infection; instead, most dogs that die of toxoplasmosis have a distemper virus infection or other immunosuppressive conditions ${ }^{2-4}$. Toxoplasmosis is recognized as an opportunistic disease in dogs, which is characterized by neuromuscular, respiratory, and gastrointestinal signs or by generalized infection, in addition to its most common neurological impairments, e.g., ataxia, behavioral changes, circling, seizures, paralysis, paraplegia, twitching, and tremors ${ }^{5,6}$. T. gondii comprises different clonal lineages that may influence the progression and severity of the disease in animals and humans ${ }^{7}$.

Dogs are the definitive hosts of N. caninum and play a pivotal role in its transmission to other animals, including cattle. Neosporosis has polymorphic clinical signs in dogs. In general, the clinical findings in dogs are similar to those of toxoplasmosis, but neurologic deficits and muscular abnormalities predominate. It also causes myocardial, pulmonary, and dermal disease in dogs ${ }^{8}$.

The similarity between symptomatic toxoplasmosis and neosporosis in dogs reinforces the importance of the differential diagnosis of these diseases. Therefore, this study aimed to determine the occurrence of toxoplasmosis and neosporosis in naturally infected dogs with neurological symptoms and the genotypes circulating in this species.

\section{METHODS}

This study was conducted in the ambulatory attendance clinic of the Infectious Disease Section, School of Veterinary Medicine and Animal Science (FMVZ), São Paulo State University (UNESP), São Paulo, Brazil. 


\section{Studied animals}

Fifty dogs admitted to the Veterinary Hospital from September 2009 to July 2010 presenting with neurological symptoms, such as ataxia, seizures, behavioral changes, paralysis and paraplegia of limbs, and tremors, were studied.

For the bioassay of T. gondii, 30-day-old, non-isogenic, Swiss albino female mice (Mus musculus) were used. For the bioassay of N. caninum, 30-40-day-old, non-isogenic, female gerbils (Meriones unguiculatus) were used.

\section{Serology}

Dog serum samples were screened for T. gondii and N. caninum antibodies. Serum samples were diluted 4-fold in phosphate-buffered saline $(0.01 \mathrm{~mol} / \mathrm{L}, \mathrm{pH} 7.2)$ from a $1: 16$ dilution and promptly tested using an immunofluorescent antibody test (IFAT) for T. gondii immunoglobin $\mathrm{G}(\mathrm{IgG})$ antibodies, as described by Camargo ${ }^{9}$, and for $N$. caninum IgG antibodies under a fluorescence microscope (Zeiss SG250), as described by Dubey et al. ${ }^{3}$, using 1:25 as a cut-off point. Both tests were performed using a commercially available mouse fluorescin isothiocynale (FITC)-labeled IgG Fc antibody conjugate (Bethyl Laboratories Inc., USA). Positive sera controls for toxoplasmosis were obtained by the chronic infection of mice inoculated with the $\mathrm{RH}$ strain by the subcutaneous (s.c.) route; while for neosporosis, they were obtained by the chronic infection of gerbils inoculated with the NC-1 strain by the s.c. route. Negative control sera for toxoplasmosis and neosporosis were obtained from mice and gerbils, respectively, inoculated with sterile saline solution by the s.c. route.

For the serological test, tachyzoites of N. caninum (NC-1 strain) and T. gondii (RH strain) were used as antigens. Dog serum samples showing complete (non-polar or bipolar) parasite fluorescence at dilutions $\geq 1: 16$ or $\geq 1: 25$ for toxoplasmosis and neosporosis, respectively, were classified as positive.

\section{Bioassay in the experimental models}

Brain samples from all seropositive animals were bioassayed by s.c. injection with $1 \mathrm{~mL}$ of each tissue sample in 4 mice for the isolation of T. gondii and 4 gerbil for the isolation of N. caninum, on the basis of its specific serology ${ }^{10}$. Peritoneal fluid from all of the mice or gerbils that died was examined for T. gondii and N. caninum tachyzoites. From the surviving animals, blood was collected by retroorbital sinus puncture on day 30 post-inoculation. The animals were considered positive when tachyzoites or tissue cysts were found in the brain or when showing positive serology in IFAT ${ }^{3}$.

\section{Polymerase chain reaction}

The extraction and purification of DNA from brain samples were carried out by using the Illustra Tissue and Cells GenomicPrep Mini Spin Kit (GE Healthcare Life Sciences do Brasil Ltda, Brazil).

Polymerase chain reaction was performed by using the primers TOX4 and TOX5 described by Homan et al. ${ }^{11}$, which amplify a 529-base pair (bp) fragment, AF146527 (GenBank), and repeated 200- to 300-times in the T. gondii genome. PCR for N. caninum was performed using the species-specific primer pair Np21-Np6, directed to the genomic Nc-5 region, which amplify a 328-bp fragment ${ }^{12}$.

\section{Genotyping}

Strain typing was performed using 11 genetic markers: SAG1, SAG2 (5'-3'SAG2, and alt-SAG2), SAG3, Btub, GRA6, c22-8, c29-2, L358, PK1, Apico, and CS3, as previously described ${ }^{13-16}$. CS3 marker was included in the present study to evaluate virulence ${ }^{17}$. Reference strains (GT1, PTG, CTG, TgCgCa1, MAS, and TgCatBr5) were used for control reactions. The target DNA sequences were first amplified by multiplex-PCR using external primers for all markers, followed by nested-PCR for individual markers for genotyping, as previously described ${ }^{13-16}$. All products were visualized through electrophoresis in a 2.5 or $3 \%$ agarose gel, depending on the marker, stained with ethidium bromide, and recorded using the digital Gel-Doc-it system (UVP, USA).

\section{Statistical analysis}

Statistics associated with the results from the bioassay and PCR were calculated by adopting antibody detection as a standard screening test using the spreadsheet described by Mackinnon ${ }^{18}$. The associations between the epidemiological variables and the serological results were analyzed by the chi-square or Fisher's exact tests, considering $\alpha=0.05^{19}$. For the analysis of the results, concordance testing was performed among the serology, bioassay, and PCR data using the $\mathrm{McNemar}$ test $\mathrm{t}^{20}$. All tests were carried out using the EpiInfo ${ }^{\mathrm{TM}}$ v.3.5.1 program ${ }^{21}$

\section{Ethical considerations}

This study was approved by the Ethics Committee for Animal Experimentation, FMVZ, UNESP, Botucatu Campus (65/2006-CEEA).

\section{RESULTS}

Of the 50 animals studied, 11 (22\%; 95\% confidence interval (CI95\%), 12.8-35.3\%) were positive for toxoplasmosis, 4 at titer of 1:16, 4 at $1: 64,1$ at $1: 256,1$ at $1: 1,024$, and 1 at 1:4,096. Seven animals (14\%; CI95\%I, 7.0-26.3\%) were positive for neosporosis, 2 dogs at a titer of $1: 25,2$ at $1: 50$, and 3 at 1:100. In the bioassay and PCR, 7/11 (63.6\%; CI95\%, 34.9-84.8\%) samples were positive for toxoplasmosis. For neosporosis, $2 / 7$ (28.6\%; CI95\%, 8.52-65.09) samples were positive in the bioassay and 3/7 (42.9\%; CI95\%I, 15.7-75.5\%) were positive in PCR. Two dogs were positive for both diseases. The bioassay was also carried out on 11 animals that tested negative for both diseases.

Both parasitological tests (i.e., bioassay and PCR) had a $100 \%$ agreement for toxoplasmosis and neosporosis. Comparing the results obtained by IFAT and PCR for toxoplasmosis, or IFAT and the bioassay, the tests had an $82 \%$ agreement. For the comparison of the 3 diagnostic tests for neosporosis, PCR and the bioassay had an agreement of $82.4 \%$, IFAT and the bioassay test had an agreement of $88.2 \%$, and IFAT and PCR had an agreement of $94.1 \%$.

No variables presented with significant differences for the IFAT results for the analysis of T. gondii and N. caninum antibodies. Significant associations were observed for both parasites in IFAT $[\mathrm{p}=0.038$; odds ratio $(\mathrm{OR})=6.8571(\mathrm{CI} 95 \%, 1.2503-37.6068)]$ and $\mathrm{PCR}[\mathrm{p}=0.037$; $\mathrm{OR}=21.5000(\mathrm{CI} 95 \%, 1.5810-292.3818)]$. The genotyping results and the detection rates in other studies are presented in Table $\mathbf{1 .}$

TABLE 1 - Genotypic profile of Toxoplasma gondii isolates from dog samples.

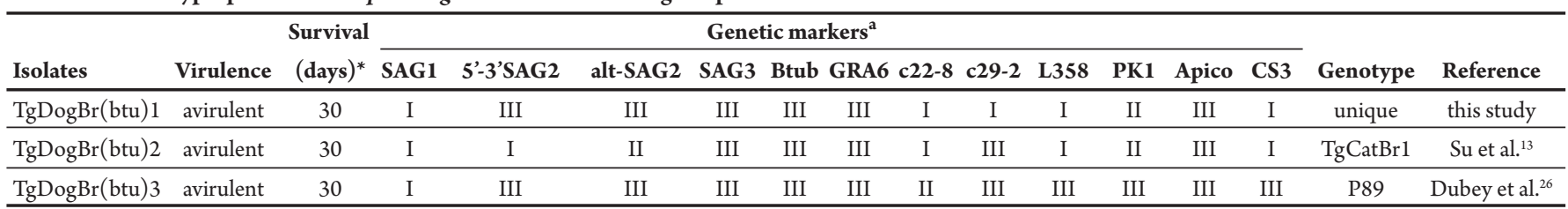

${ }^{*}$ maximum observation period $=30$ days post-inoculation. ${ }^{\text {a }}$ SAG: surface antigen; Btub: b-tubulin; GRA: dense granule; Apico: apicoplast; PK: protein kinase. 


\section{DISCUSSION}

Neurological signs of toxoplasmosis, neosporosis, and distemper are similar, emphasizing the importance of the differential diagnosis of these diseases. Toxoplasmosis is recognized as one of the most common diseases in dogs with neurological signs ${ }^{5}$, and has been related to combined infections with distemper ${ }^{22} . N$. caninum infections have been described in animals affected with toxoplasmosis and it should be considered in the differential diagnosis or with concurrent detection in cases like the present one $\mathrm{e}^{23}$.

In the present study, $T$. gondii was isolated from the brain tissue of 7 of 11 dogs with IFAT titers of $\geq 1: 16 . N$. caninum was isolated from the brain tissue of 2 of 7 dogs with IFAT titers of $\geq 1: 25$. These data are in agreement with those of Cavalcante et al. ${ }^{24}$ who identified $N$. caninum in dogs fed with masseter, heart, liver, and brain from infected cattle.

In the detection of $T$. gondii infection, PCR presented with a higher sensitivity than the conventional diagnostic methods. Two dog samples with negative results for serology and the bioassay generated positive PCR results. In this case, one can possibly suggest that these dogs had a chronic previous infection with non-detectable antibody at the 1:16 dilution, which was associated with a parasite load that was too low to be detected in the bioassay, but enough to be detected by PCR. Additionally, the sensitivity of PCR depends on whether the chosen tissue sample contains parasite DNA.

For neosporosis diagnosis, serology demonstrated a greater sensitivity; from 7 positive dogs, 2 were positive in the bioassay and 3 were positive with PCR. Additionally, serological studies using IFAT performed in different hosts have shown that there is little cross-reactivity with the coccidia of other parasites; therefore, IFAT has been considered the standard test for the diagnosis of neosporosis. PCR with the primer pair Np21/Np6 can be an efficient tool for large-scale epidemiological studies using brain tissue obtained at necropsy ${ }^{12}$. Despite the sensitivity and specificity of PCR, the brain tissue used may not have contained parasite DNA. This is a limitation of DNA detection, not only for N. caninum but also for other microorganisms. Hůrková \& Modrý25 detected N. caninum DNA in the brains of only 4.6\% (7/152) red foxes (Vulpes vulpes).

Three genotypes were identified in the present study, TgDogBr1-3. All of them were avirulent in mice. Only one $\mathrm{TgDogBr} 1$ presented with a unique genotype. $\mathrm{TgDogBr} 2$ presented with a genotype identical to the reference strain $\mathrm{TgCatBr} 1$, which was previous identified by $\mathrm{Su}$ et al. ${ }^{13}$ in cats from the State of Paraná, Brazil. $\mathrm{TgDogBr} 3$ was identical to the reference strain P89, which was previous reported by Dubey et $\mathrm{al}^{26}{ }^{26}$ in a pig from Iowa State, USA.

Phenotypic differences are observed between P89 and $\mathrm{TgDogBr}$. TgDogBr3 was avirulent, while P89 was classified as virulent for mice ${ }^{26}$, where only 1 oocyst is lethal to mice by any route of administration. $\operatorname{TgDogBr} 3$, as with the other genotypes, presented with the type I or III allele at the CS3 locus. Da Silva et al. ${ }^{27}$ observed that $5(62.5 \%)$ of 8 strains with the type II allele at the CS3 locus were avirulent in mice, while $3(37.5 \%)$ strains with the type II allele were virulent. In other reports, $82 \%$ of strains with the type II allele at the CS3 locus were virulent in mice $^{16}$, and $85.5 \%$ of strains with the type II allele at the CS3 locus were virulent in mice from another study in Brazil ${ }^{28}$. According to the classification formulated by Pena et al. ${ }^{16}, \mathrm{TgDogBr} 2$ was classified in the Type BrII group (intermediate virulence), while $\mathrm{TgDogBr} 3$ was classified in the Type BrIII group (avirulent), which correlates with the virulence observed in the present study. TgDogBr1 did not match with any of the types proposed by Pena et al. ${ }^{16}$.

These data confirm both types of infection in dogs, the importance of this host as a reservoir for these pathogens for humans, and the genotypic variation of this parasite in Brazil.

\section{ACKNOWLEDGMENTS}

The authors would like to thank Dr. Antonio Carlos Paes, Marília Franco, and Simone Mangia (Infectious Diseases Section - FMVZ/ UNESP) for her assistance with the animal hospital.

\section{CONFLICT OF INTEREST}

The authors declare that there is no conflict of interest.

\section{REFERENCES}

1. Dubey JP. Review of Neospora caninum and neosporosis in animals. Korean J Parasitol 2003a; 41:1-16.

2. Dubey JP, Ross AD, Fritz D. Clinical Toxoplasma gondii, Hammondia heydorni, and Sarcocystis sp. Infections in dogs. Parasitol 2003b; 45:141-146.

3. Dubey JP, Beattie CP. Toxoplasmosis of Animals and Man. Boca Raton (FL) CRC Press; 1988. p. 1-220.

4. Dubey JP, Carpenter JL, Topper MJ, Uggla A. Fatal toxoplasmosis in dogs. J Am Anim Hosp Assoc 1989; 25:659-664.

5. Da Silva AV, Pezerico SB, Lima VY, Moretti L, Pinheiro JP, Tanaka EM, et al Genotyping of Toxoplasma gondii strains isolated from dogs with neurological signs. Vet Parasitol 2005; 127:23-27.

6. Greene CE. Infectious diseases of the dog and cat. $3^{\text {rd }}$ ed. Philadelphia: Saunders; 2006.

7. Howe DK, Sibley LD. Toxoplasma gondii comprises three clonal lineages: correlation of parasite genotype with human disease. J Infect Dis 1995; 172:1561-1566.

8. Lindsay DS, Dubey JP, Duncan RB. Confirmation that dogs are definitive hosts for Neospora caninum. Vet Parasitol 1999; 82:327-333.

9. Camargo ME. Improved technique of indirect immunofluorescence for serological diagnosis of toxoplasmosis. Rev Inst Med Trop 1964; 6:117-118.

10. Dubey JP. Refinement of pepsin digestion method for isolation of Toxoplasma gondii from infected tissues. Vet Parasitol 1998; 74:75-77.

11. Homan WL, Vercammen M, De Braeleleer J, Verschueren H. Identification of a 200- to 300- fold repetitive 529bp DNA fragment in Toxoplasma gondii, and its use for diagnostic and quantitative PCR. Int J Parasitol 2000; 30:69-75.

12. Yamage M, Flechtner O, Gottstein B. Neospora caninum: Speciûc oligonucleotide primers for the detection of brain "cyst" DNA of experimentally infected nude mice by the polymerase chain reaction (PCR). J Parasitol 1996; 82:272-279.

13. Su C, Zhang X, Dubey JP. Genotyping of Toxoplasma gondii by multilocus PCR-RFLP markers: A high resolution and simple method for identification of parasites. Int J Parasitol 2006; 36:841-848.

14. Ferreira IMR, Vidal JE, Costa-Silva TA, Meira CS, Hiramoto RM, Oliveira ACP, et al. Toxoplasma gondii: genotyping of strains from Brazilian AIDS patients with cerebral toxoplasmosis by multilocus PCR-RFLP markers. Exp Parasitol 2008; 118:221-227.

15. Dubey JP, Sundar N, Gennari SM, Minervino AHH, Farias NADR, Ruas JL, et al. Biologic and genetic comparison of Toxoplasma gondii isolates in freerange chickens from the northern Pará state and the southern state Rio Grande do Sul, Brazil revealed highly diverse and distinct parasite populations. Vet Parasitol 2007; 143:182-188.

16. Pena HFJ, Gennari SM, Dubey JP, Su C. Population structure and mousevirulence of Toxoplasma gondii in Brazil. Int J Parasitol 2008; 38:561-569. 
17. Khan A, Taylor S, Su C, Mackey AJ, Boyle J, Cole R, et al. Composite genome map and recombination parameters derived from three archetypal lineages of Toxoplasma gondii. Nuc Acids Res 2005; 33:2980-2992.

18. Mackinnon A. A spreadsheet for the calculation of comprehensive statistics for the assessment of diagnostic tests and inter-rater agreement. Comput Biol Med 2000; 30:127-134.

19. Triola MF. Introdução à estatística. $9^{\text {th }}$ ed. Rio de Janeiro: LTC - Livros Tecnicos e Cientificos Editora SA; 2005.

20. Zar JH. Biostatistical analysis. $4^{\text {th }}$ ed. Upper Saddle River: Prentice Hall; 1999.

21. Centers for Disease Control (CDC) Epi Info [Internet]. 2002. [Cited 2009 August 14]. Available from: http://www.cdc.gov/epiinfo/ei2002.htm/.

22. Brito AF, Souza LC, Silva AV, Langoni H. Epidemiological and serological aspects in canine toxoplasmosis in animals with nervous symptoms. Mem Inst Oswaldo Cruz 2002; 97:31-35.

23. Mineo TW, Silva DA, Costa GH, Von Ancken AC, Kasper LH, Souza MA, et al. Detection of IgG antibodies to Neospora caninum and Toxoplasma gondii in dogs examined in a veterinary hospital from Brazil. Vet Parasit 2001; 98:239-245.
24. Cavalcante GT, Monteiro RM, Soares RM, Nishi SM, Alves Neto AF, Esmerini PO, et al. Shedding of Neospora caninum oocysts by dogs fed different tissues from naturally infected cattle. Vet Parasitol 2011; 179:220-223

25. Hùrkova L, Modrý D. PCR detection of Neospora caninum, Toxoplasma gondii and Encephalitozoon cuniculi in brains of wild carnivores. Vet Parasitol 2006; 137:150-154

26. Dubey JP, Thulliez P, Powell EC. Toxoplasma gondii in Iowa sows: comparison of antibody titers to isolation of T. gondii by bioassays in mice and cats. J Parasitol 1995; 81:48-53.

27. Silva RC, Langoni H, Su C, Silva AV. Genotypic characterization of Toxoplasma gondii in sheep from Brazilian slaughterhouses: New atypical genotypes and the clonal type II strain identified. Vet Parasitol 2011; 175:173-177.

28. Yai LEO, Ragozo AMA, Soares RM, Pena HFJ, Su C, Gennari SM. Genetic diversity among capybara (Hydrochaeris hydrochaeris) isolates of Toxoplasma gondii from Brazil. Vet Parasitol 2009; 162:332-337. 